\title{
Synthesis, structure and properties of $\mathrm{N}$-alkoxy- $\mathrm{N}$-(1-pyridinium)urea salts, $\mathrm{N}$-alkoxy- $\mathrm{N}$-acyloxyureas and $\mathrm{N}, \mathrm{N}$-dialkoxyureas ${ }^{\dagger}$
}

\author{
Vasiliy G. Shtamburg, ${ }^{a}$ Oleg V. Shishkin, ${ }^{b}$ Roman I. Zubatyuk, ${ }^{b}$ Svetlana V. Kravchenko, ${ }^{a}$ \\ Alexander V. Tsygankov, ${ }^{a}$ Victor V. Shtamburg, ${ }^{c}$ Vitaliy B. Distanov ${ }^{c}$ and Remir G. Kostyanovsky ${ }^{* d}$ \\ ${ }^{a}$ Department of Chemistry, Dnepropetrovsk National University, 49050 Dnepropetrovsk, Ukraine. \\ E-mail: heterocycle@ff.dsu.dp.ua \\ b STC 'Institute for Single Crystals', National Academy of Sciences of Ukraine, 61001 Kharkov, Ukraine. \\ E-mail: shishkin@xray.isc.kharkov.com \\ ${ }^{c}$ Department of Chemistry, National Technical University, Kharkov Polytechnic Institute, 61002 Kharkov, \\ Ukraine.E-mail: vitalius2002@ukr.net \\ ${ }^{d}$ N. N. Semenov Institute of Chemical Physics, Russian Academy of Sciences, 119991 Moscow, \\ Russian Federation. Fax: +7 495137 8284; e-mail: kost@chph.ras.ru
}

DOI: $10.1016 /$ j.mencom.2007.05.016

$N$-Alkoxy- $N$-(1-pyridinium)urea salts 3, 4 have been prepared, the conversions of $N$-acetoxy- $N$-methoxyurea 7 into $N, N$-dimethoxyurea 8 and of $N$ - $n$-propyloxy- $N$-(1-pyridinium)- $N^{\prime}, N^{\prime}$-dimethylurea chloride 6 into $N, N$-dimethoxy- $N^{\prime}, N^{\prime}$-dimethylurea 11 were carried out. A high pyramidality of the amide nitrogen in $\mathrm{O}-\mathrm{N}-\mathrm{X}$ groups $\left[\mathrm{X}=\mathrm{N}^{+} \mathrm{C}_{5} \mathrm{H}_{5}, \mathrm{OMe}, \mathrm{OC}(\mathrm{O}) \mathrm{C}_{6} \mathrm{H}_{4} \mathrm{Cl}-p\right]$ has been revealed by XRD studies of ureas $3 \mathbf{b}, 8$ and $N$-p-chlorobenzoyloxy- $N$ - $n$-butyloxyurea 9.

The pyramidality of amide nitrogen was found earlier in acyclic anomeric amides ${ }^{2}$ such as $N, N$-dialkoxy- $N^{\prime}, N^{\prime}$-dimethylureas by the DNMR method ${ }^{3}$ and XRD studies in $N$-acyloxy- $N$-alkoxybenzamides, ${ }^{4} N, N^{\prime}$-diacyl- $N, N^{\prime}$-dialkoxyhydrazines, ${ }^{5} N$-acyloxy$N$-alkoxyureas, ${ }^{6(a)} N$-acyloxy- $N$-alkoxycarbamates ${ }^{6(a)}$ and $N$-chloro$N$-alkoxyureas. ${ }^{1}$ However, $N$-alkoxy- $N$-(1-pyridinium) urea salts have never been regarded as a kind of anomeric amides and the pyramidality parameters of unsubstituted $N, N$-dialkoxyureas were unknown.

We have synthesised salts $\mathbf{3}, \mathbf{4}^{\ddagger}$ and $\mathbf{6}$ by nucleophilic

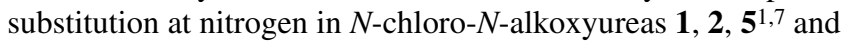
performed an XRD study of $\mathbf{3 b}$ (Figure 1, Tables 1, 2).<smiles>[R][R]#[R][X]</smiles><smiles>[R]ON(C(N)=O)[n+]1ccccc1[X]</smiles>

3a $\mathrm{R}=\mathrm{Me}, \mathrm{X}=\mathrm{Cl}$

$\begin{array}{ll}\text { 3b } & \mathrm{R}=\mathrm{Me}, \mathrm{X}=\mathrm{ClO}_{4} \\ 4 \mathrm{R} & =\mathrm{Et}, \mathrm{X}=\mathrm{Cl}\end{array}$<smiles>CCCON(Cl)C(=O)N(C)C</smiles><smiles>CCCON(C(=O)NC)[n+]1ccccc1Cl</smiles>

6

Scheme 1 Reagents and conditions: $\mathrm{i}, \mathrm{Py}, \mathrm{Et}_{2} \mathrm{O}$, room temperature; ii, $\mathrm{AgClO}_{4}, \mathrm{MeCN}$.

In order to investigate the structure of the simplest $\mathrm{N}, \mathrm{N}$-dialkoxyurea by methanolysis of $N$-acetoxy- $N$-methoxyurea 7 , crystalline $N, N$-dimethoxyurea $\mathbf{8}^{1}$ was obtained (Scheme 2 ) and studied by XRD analysis (Figure 2, Tables 1,2).

Chlorides 3a, 4 are stable at room temperature for $12 \mathrm{~h}$ and decompose at long-duration storage at $-5^{\circ} \mathrm{C}$ (10 weeks). Chloride 6 can be stored without decomposition at $-5^{\circ} \mathrm{C}$ for

Asymmetric Nitrogen, Part 100. Geminal Systems, Part 57. Previous communication, see ref. 1 .
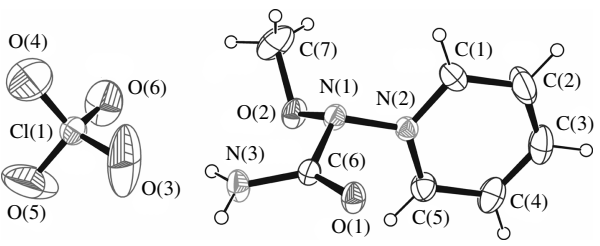

Figure 1 Molecular structure of $\mathbf{3 b}$. Selected bond lengths $(\AA)$ and bond angles $\left({ }^{\circ}\right)$ : $\mathrm{N}(1)-\mathrm{C}(6) 1.4515(19), \mathrm{N}(3)-\mathrm{C}(6)$ 1.3234(18), $\mathrm{O}(1)-\mathrm{C}(6)$ 1.2218(17), $\mathrm{N}(1)-\mathrm{N}(2)$ 1.4254(18), O(2)-N(1) 1.3999(17), O(2)-C(7) 1.442(3), N(2)$\mathrm{C}(1) 1.341(2), \mathrm{N}(2)-\mathrm{C}(5) 1.341(2) ; \mathrm{O}(2)-\mathrm{N}(1)-\mathrm{N}(2) 109.03(12), \mathrm{O}(2)-\mathrm{N}(1)$ C(6) 113.03(12), N(2)-N(1)-C(6) 111.72(11), N(1)-O(2)-C(7) 108.94(18), $\mathrm{C}(5)-\mathrm{N}(2)-\mathrm{N}(1) 120.44(13), \mathrm{C}(5)-\mathrm{N}(2)-\mathrm{C}(1) 123.61(16), \mathrm{C}(1)-\mathrm{N}(2)-\mathrm{N}(1)$ $115.95(15)$

more than one year, but it is very hygroscopic. Chloride 3a was converted into more stable perchlorate $\mathbf{3 b}$. This allowed us to perform an XRD study ${ }^{\S}$ at room temperature without any decomposition of the crystal. The results revealed that amide nitrogen in the $\mathrm{O}-\mathrm{N}-\mathrm{N}^{+}$system has a pyramidal configuration (Figure 1, Tables 1,2). The nitrogen pyramidality parameters as the sum of bond angles centered at this atom $(\Sigma \beta)$ and the deviation of $\mathrm{N}(1)$ from the plane of three atoms it is bonded with $\left(h_{\mathrm{N}}\right)$ are given in Table 1 . In $N$-alkoxy- $N$-(1-pyridinium)urea salt $\mathbf{3 b}$, the $\mathrm{N}$ pyramidality degree is less as it was found for $N$-alkoxy- $N$-(1-pyridinium)- $N$-tert-alkylamine salts, ${ }^{8}$ but it is closer to $\mathrm{N}$ pyramidality in $N$-acetoxy- $N$-ethoxyurea ${ }^{6(a)}$ and methyl $N$-4-chlorobenzoyloxy- $N$-methoxycarbamate. ${ }^{6(a)}$ The decreasing nitrogen pyramidality degree in salt $\mathbf{3 b}$ against the $N$-alkoxy- $N$-(1-pyridinium)- $N$-tert-alkylamine salt ${ }^{8}$ can be explained by stabilization of the planar configuration of amide

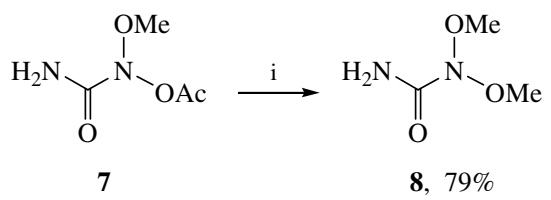

Scheme 2 Reagents and conditions: i, $\mathrm{MeOH}$, room temperature. 


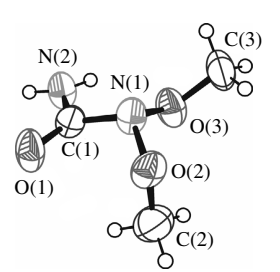

Figure 2 Molecular structure of $\mathbf{8}$. Selected bond lengths $(\AA)$ and bond angles $\left({ }^{\circ}\right)$ : $\mathrm{N}(1)-\mathrm{C}(1) 1.438(2), \mathrm{N}(2)-\mathrm{C}(1) 1.320(3), \mathrm{O}(1)-\mathrm{C}(1) 1.220(2)$, $\mathrm{O}(2)-\mathrm{N}(1)$ 1.397(2), O(3)-N(1) 1.401(2), O(2)-C(2) 1.431(3), O(3)-C(3) 1.429(2), O(2)-N(1)-O(3) 110.33(13), O(2)-N(1)-C(1) 111.37(16), O(3)$\mathrm{N}(1)-\mathrm{C}(1) \quad 110.07(14), \quad \mathrm{O}(1)-\mathrm{C}(1)-\mathrm{N}(2) \quad 125.61(19), \quad \mathrm{O}(1)-\mathrm{C}(1)-\mathrm{N}(1)$ $118.78(16), \mathrm{N}(2)-\mathrm{C}(1)-\mathrm{N}(1) 115.2(2), \mathrm{N}(1)-\mathrm{O}(2)-\mathrm{C}(2) 114.17(16), \mathrm{N}(1)-$ $\mathrm{O}(3)-\mathrm{C}(3)$ 109.19(16).

\# N-Methoxy-N-(1-pyridinium)urea chloride 3a. A solution of pyridine ( $95 \mathrm{mg}, 1.206 \mathrm{mmol})$ in $\mathrm{Et}_{2} \mathrm{O}(2 \mathrm{ml})$ was added to a solution of $N$-chloro$N$-methoxyurea $\mathbf{1}^{1}(135 \mathrm{mg}, 1.085 \mathrm{mmol})$ in $\mathrm{Et}_{2} \mathrm{O}(3 \mathrm{ml})$ at $-30{ }^{\circ} \mathrm{C}$. During $3 \mathrm{~h}$, the reaction mixture was heated to $5{ }^{\circ} \mathrm{C}$ and kept at this temperature for $40 \mathrm{~h}$. The obtained solid was filtered off, washed with $\mathrm{Et}_{2} \mathrm{O}$ and dried in vacuo, yielding $198 \mathrm{mg}(89 \%)$ of urea 3a, white crystals, mp 97-98 ${ }^{\circ} \mathrm{C}$ (decomp.). ${ }^{1} \mathrm{H}$ NMR (300 MHz, $\left.\left[{ }^{2} \mathrm{H}_{6}\right] \mathrm{DMSO}\right) \delta$ : 3.90 (s, $3 \mathrm{H}, \mathrm{OMe}$ ), 8.31 (br. s, $2 \mathrm{H}, \mathrm{NH}_{2}$ ), 8.32 [t, $2 \mathrm{H}, \mathrm{C}(3) \mathrm{H}, \mathrm{C}(5) \mathrm{H}$, ${ }^{3} J 7.5 \mathrm{~Hz}$ ], 8.83 [t, 1H, C(4)H, ${ }^{3} J 7.5 \mathrm{~Hz}$ ], 9.40 [d, 2H, C(2)H, C(6)H, $\left.{ }^{3} J 5.7 \mathrm{~Hz}\right]$. IR $\left(v / \mathrm{cm}^{-1}\right): 3285(\mathrm{NH}), 1745(\mathrm{C}=\mathrm{O})$. MS $\left(\mathrm{FAB}, \mathrm{H}^{+}\right), \mathrm{m} / \mathrm{z}(\%)$ : $168\left(\mathrm{M}^{+}, 100\right)$. Found (\%): C, 41.18; H, 5.02; N, 20.75; Cl, 17.32. Calc. for $\mathrm{C}_{7} \mathrm{H}_{10} \mathrm{~N}_{3} \mathrm{O}_{2} \mathrm{Cl}(\%)$ : C, 41.29; H, 4.95; N, 20.64; Cl, 17.41 .

In a similar manner, $N$-ethoxy- $N$-(1-pyridinium)urea chloride 4 was obtained from $N$-chloro- $N$-ethoxyurea $2,{ }^{7}$ colourless crystals, yield $73 \%$, mp $124-125{ }^{\circ} \mathrm{C}$ (decomp.). ${ }^{1} \mathrm{H}$ NMR (300 MHz, $\left.\left[{ }^{2} \mathrm{H}_{6}\right] \mathrm{DMSO}\right) \delta: 1.21$ (t, $3 \mathrm{H}, \mathrm{NOCH}_{2} \mathrm{Me},{ }^{3} \mathrm{~J} 7.2 \mathrm{~Hz}$ ), 3.98 (q, 2H, $\left.\mathrm{NOCH}_{2} \mathrm{Me},{ }^{3} \mathrm{~J} 7.2 \mathrm{~Hz}\right), 8.22$ $\left[\mathrm{t}, 2 \mathrm{H}, \mathrm{C}(3) \mathrm{H}, \mathrm{C}(5) \mathrm{H},{ }^{3} \mathrm{~J} 7.8 \mathrm{~Hz}\right.$ ], 8.65 [t and br. s, $3 \mathrm{H}, \mathrm{NH}_{2}, \mathrm{C}(4) \mathrm{H}$, $\left.{ }^{3} J 7.8 \mathrm{~Hz}\right], 9.25$ [d, 2H, C(2)H, C(6)H, $\left.{ }^{3} J 7.8 \mathrm{~Hz}\right]$. IR $\left(v / \mathrm{cm}^{-1}\right): 3270(\mathrm{NH})$, $1750(\mathrm{C}=\mathrm{O})$. Found $(\%)$ : N, 19.12; $\mathrm{Cl}, 16.05$. Calc. for $\mathrm{C}_{8} \mathrm{H}_{12} \mathrm{~N}_{3} \mathrm{O}_{2} \mathrm{Cl}$ (\%): N, 19.31; Cl, 16.29.

In a similar manner, $N$ - $n$-propyloxy- $N$-(1-pyridinium)- $N^{\prime}, N^{\prime}$-dimethylurea chloride 6 was obtained from $N$-chloro- $N$ - $n$-propyloxy- $N^{\prime}, N^{\prime}$-dimethylurea $5,{ }^{7}$ colourless crystals, yield $77 \%, \mathrm{mp} 83-84{ }^{\circ} \mathrm{C}$ (decomp.). ${ }^{1} \mathrm{H}$ NMR $\left(300 \mathrm{MHz}, \mathrm{CDCl}_{3}\right) \delta: 0.95$ (t, $3 \mathrm{H}, \mathrm{NOCH}_{2} \mathrm{CH}_{2} \mathrm{Me}, J 7.2 \mathrm{~Hz}$ ), 1.68 (sext, $2 \mathrm{H}, \mathrm{NOCH}_{2} \mathrm{CH}_{2} \mathrm{Me},{ }^{3} \mathrm{~J} 7.2 \mathrm{~Hz}$ ), 3.09 (s, 3H, NMe), 3.35 (s, 3H, NMe), 4.17 (t, 2H, NOCH $\left.\mathrm{CH}_{2} \mathrm{Me},{ }^{3} \mathrm{~J} 7.2 \mathrm{~Hz}\right), 8.42[\mathrm{t}, 2 \mathrm{H}, \mathrm{C}(3) \mathrm{H}, \mathrm{C}(5) \mathrm{H}$, ${ }^{3} J 7.8 \mathrm{~Hz}$ ], 8.78 [t, $\left.1 \mathrm{H}, \mathrm{C}(4) \mathrm{H},{ }^{3} J 7.8 \mathrm{~Hz}\right], 9.59[\mathrm{~d}, 2 \mathrm{H}, \mathrm{C}(2) \mathrm{H}, \mathrm{C}(6) \mathrm{H}$, ${ }^{3} J 7.8 \mathrm{~Hz}$. IR $\left(v / \mathrm{cm}^{-1}\right)$ : $1745(\mathrm{C}=\mathrm{O})$. Found $(\%): \mathrm{N}, 16.01 ; \mathrm{Cl}, 13.74$. Calc. for $\mathrm{C}_{11} \mathrm{H}_{18} \mathrm{ClN}_{3} \mathrm{O}_{2}(\%)$ : N, 16.18; $\mathrm{Cl}, 13.65$.

$\mathrm{N}-$ Methoxy-N-(1-pyridinium) urea perchlorate $3 \mathbf{b}$. A solution of $\mathrm{AgClO}_{4}$ (139 $\mathrm{mg}, 0.670 \mathrm{mmol})$ was added to a solution of urea 3a $(137 \mathrm{mg}$, $0.670 \mathrm{mmol})$ in a mixture of $\mathrm{MeCN}(5 \mathrm{ml})$ and $\mathrm{MeOH}(2 \mathrm{ml})$. The $\mathrm{AgCl}$ precipitate was filtered off; the filtrate was evaporated in vacuo. The obtained residue was washed by THF and crystallised from MeCN$\mathrm{CH}_{2} \mathrm{Cl}_{2}$ at $-20^{\circ} \mathrm{C}$, yielding $159 \mathrm{mg}(88 \%)$ of urea $\mathbf{3 b}$, colourless crystals, mp $128-130{ }^{\circ} \mathrm{C}$ (decomp.). ${ }^{1} \mathrm{H}$ NMR (300 MHz, $\left.\left[{ }^{2} \mathrm{H}_{6}\right] \mathrm{DMSO}\right) \delta: 3.90$ (s, 3H, OMe), 8.29 (br. s, 2H, NH$H_{2}$ ), 8.32 [t, 2H, C(3)H, C(5)H, ${ }^{3} J 7.5 \mathrm{~Hz}$ ], 8.83 [t, 1H, C(4)H, ${ }^{3} J 7.5 \mathrm{~Hz}$ ], 9.39 [d, 2H, C(2)H, C(6)H, ${ }^{3} J 5.7 \mathrm{~Hz}$. MS (FAB, $\left.\mathrm{H}^{+}\right)$: $168\left(\mathrm{M}^{+}, 100\right)$. Found (\%): C, 31.23; H, 3.92; N, 15.45. Calc. for $\mathrm{C}_{7} \mathrm{H}_{10} \mathrm{~N}_{3} \mathrm{O}_{6} \mathrm{Cl}(\%)$ : C, 31.42; H, 3.77; N, 15.70 .

$\mathrm{N}, \mathrm{N}$-Dimethoxyurea 8. $\mathrm{N}$-Acetoxy- $\mathrm{N}$-methoxyurea $7^{1}(87 \mathrm{mg}, 0.598 \mathrm{mmol})$ was dissolved in $\mathrm{MeOH}(2 \mathrm{ml})$, and the solution was kept at $22{ }^{\circ} \mathrm{C}$ for $74 \mathrm{~h}$. Then, it was evaporated in vacuo; the residue was kept at 2 Torr and crystallised from $\mathrm{Et}_{2} \mathrm{O}$-hexane, yielding $57 \mathrm{mg}(79 \%)$ of urea 8, colourless crystals, mp $47-48^{\circ} \mathrm{C}$, identified by ${ }^{1} \mathrm{H}$ NMR with a sample ${ }^{1}$ obtained from $N$-chloro- $N$-methoxyurea $\mathbf{1}^{1}$. MS $\left(\mathrm{FAB}, \mathrm{H}^{+}\right), m / z: 121$ $\left([\mathrm{M}+\mathrm{H}]^{+}, 100\right)$.

Methanolysis of $\mathrm{N}$-n-propyloxy-N-(1-pyridinium)-N', N'-dimethylurea chloride 6. A solution of salt $6(199 \mathrm{mg}, 0.766 \mathrm{mmol})$ in $\mathrm{MeOH}(3 \mathrm{ml})$ was refluxed for $3 \mathrm{~h}$; then, it was evaporated in vacuo. The residue was extracted by $\mathrm{Et}_{2} \mathrm{O}(10 \mathrm{ml})$, the extract was evaporated in vacuo. By NMR, the residue is a mixture of $N, N$-dimethoxyurea $11^{3}$ (main component) with trace $N$ - $n$-propyloxy- $N$-methoxyurea $10 .{ }^{7}$ After distillation in vacuo, $11 \mathrm{mg}(10 \%)$ of $N, N$-dimethoxy- $N^{\prime}, N^{\prime}$-dimethylurea 11 was obtained and identified by ${ }^{1} \mathrm{H}$ NMR spectroscopy. ${ }^{3,7}{ }^{1} \mathrm{H}$ NMR $(300 \mathrm{MHz}$, $\left.\mathrm{CDCl}_{3}\right) \delta: 3.00\left(\mathrm{~s}, 6 \mathrm{H}, \mathrm{NMe}_{2}\right), 3.75\left[\mathrm{~s}, 6 \mathrm{H}, \mathrm{N}(\mathrm{OMe})_{2}\right]$.
Table 1 Parameters of nitrogen atom pyramidality in $\mathrm{Y}-\mathrm{N}(\mathrm{X}) \mathrm{OR}$ compounds.

\begin{tabular}{lllll}
\hline $\mathrm{Y}$ & $\mathrm{X}$ & $\mathrm{R}$ & $h_{\mathrm{N}} / \AA$ & $\Sigma \beta /^{\circ}$ \\
\hline $\mathrm{H}_{2} \mathrm{NC}(\mathrm{O})$ & $\mathrm{OMe}$ & $\mathrm{Me}(\mathbf{8})$ & 0.444 & 331.8 \\
$\mathrm{H}_{2} \mathrm{NC}(\mathrm{O})$ & $\mathrm{Cl}^{1}$ & $\mathrm{Me}$ & 0.500 & 329.0 \\
$\mathrm{O}_{2} \mathrm{NC}_{6} \mathrm{H}_{4} \mathrm{HNC}(\mathrm{O})$ & $\mathrm{Cl}^{1}$ & $\mathrm{CMe}_{2} \mathrm{CO}_{2} \mathrm{Me}$ & 0.533 & 325.8 \\
$\mathrm{H}_{2} \mathrm{NC}(\mathrm{O})$ & $\mathrm{OAc}^{6(a)}$ & $\mathrm{Et}$ & 0.431 & 333.6 \\
$\mathrm{H}_{2} \mathrm{NC}(\mathrm{O})$ & $\mathrm{OC}(\mathrm{O}) \mathrm{C}_{6} \mathrm{H}_{4} \mathrm{Cl}-p$ & $\mathrm{Bu}^{\mathrm{n}}(\mathbf{9})$ & 0.511 & 323.8 \\
$\mathrm{H}_{2} \mathrm{NC}(\mathrm{O})$ & $\mathrm{N}^{+} \mathrm{C}_{5} \mathrm{H}_{5}$ & $\mathrm{Me}(\mathbf{3 b})$ & 0.429 & 333.9 \\
$\mathrm{MeO}_{2} \mathrm{CMe}{ }_{2} \mathrm{C}$ & $\mathrm{N}^{+} \mathrm{C}_{5} \mathrm{H}_{5}{ }^{8}$ & $\mathrm{Me}$ & 0.531 & 322.8 \\
$\mathrm{Bz}$ & $\mathrm{OBz}^{4}$ & $\mathrm{CH}_{2} \mathrm{C}_{6} \mathrm{H}_{4} \mathrm{Bu}^{\mathrm{t}}-p$ & 0.508 & 324.14 \\
$p-\mathrm{Bu} \mathrm{C}_{6} \mathrm{H}_{4} \mathrm{C}(\mathrm{O})$ & $\mathrm{OC}(\mathrm{O}) \mathrm{C}_{6} \mathrm{H}_{4} \mathrm{Bu}^{\mathrm{t}}-p^{4}$ & $\mathrm{CH}_{2} \mathrm{C}_{6} \mathrm{H}_{4} \mathrm{Bu}^{\mathrm{t}}-p$ & 0.513 & 323.51 \\
$\mathrm{MeOC}(\mathrm{O})$ & $\mathrm{OC}(\mathrm{O}) \mathrm{C}_{6} \mathrm{H}_{4} \mathrm{Cl}_{-} p^{6(a)}$ & $\mathrm{Me}$ & 0.426 & 334.1 \\
\hline
\end{tabular}

nitrogen due to conjugation with the carbonyl group. The nitrogen pyramidality parameters in different $\mathrm{O}-\mathrm{N}-\mathrm{X}$ geminal systems are given in Table 1 . Earlier, we believed that $N$-acyloxy$\mathrm{N}$-alkoxybenzamides are most strongly pyramidal at nitrogen. ${ }^{4}$ But, as we have found by means of XRD study, in $N$ - $p$-chlorobenzoyloxy- $N$ - $n$-butyloxyurea $\mathbf{9}^{6(b)}$ the nitrogen pyramidality parameters $h_{\mathrm{N}}$ and $\Sigma \beta$ were close to those of $N$-acyloxy$N$-alkoxybenzamides ${ }^{4}$ (Table 1 ). The conformation of urea 9 (Figure 3) is similar to the conformation of $N$-acyloxy- $N$-alkoxybenzamides. ${ }^{4}$ In urea $\mathbf{9}$, the nitrogen pyramidality degree is higher than that in the Kirby 'most twisted' amide (1-aza2 -adamantanone ${ }^{9}$ ). We suppose that the high degree of nitrogen pyramidality in urea 9 is caused by the $O$-butyl group.

In urea $\mathbf{3 b}$, the lone electron pair $(\mathrm{Lp})$ of $\mathrm{N}(1)$ is oriented in the pyridine ring plane [the torsion angle $\mathrm{C}(1)-\mathrm{N}(2)-\mathrm{N}(1)-\mathrm{Lp}(\mathrm{N} 1)$ is equal to $0.2^{\circ}$ ] similarly to $N$-methoxy- $N$-(1-pyridinium)$N$-tert-alkylamine perchlorate. ${ }^{8}$ It is interesting to note some differences in amide $\mathrm{N}-\mathrm{C}$ bonds in urea $\mathbf{3 b}$. The $\mathrm{N}(1)-\mathrm{C}(6)$ bond is much longer than the $\mathrm{N}(3)-\mathrm{C}(6)$ bond (see Table 2). It is probably the sequence of different degrees of carbonyl $\mathrm{C}(6)=\mathrm{O}(1)$ conjugation with $s p^{2}$-hybridized $\mathrm{N}(3)$ and $s p^{3}$ -

$\S$ Crystal data for $3 \mathbf{b}$ : crystals were grown from $\mathrm{MeCN}-\mathrm{CH}_{2} \mathrm{Cl}_{2}$ at $-20{ }^{\circ} \mathrm{C}$, $\left[\mathrm{C}_{7} \mathrm{H}_{10} \mathrm{~N}_{3} \mathrm{O}_{2}\right]^{+}\left[\mathrm{ClO}_{4}\right]^{-}$, monoclinic, space group $P 2 / n, a=9.733(2)$, $b=0.330(2)$ and $c=11.929(3) \AA, \beta=103.77(2)^{\circ}, V=1164.9(4) \AA^{3}$, $F(000)=552, d_{\text {calc }}=1.526 \mathrm{~g} \mathrm{~cm}^{-3}, Z=4, \mu=0.35 \mathrm{~mm}^{-1}$.

Crystal data for 8 : crystals were grown from $\mathrm{Et}_{2} \mathrm{O}$-hexane at $-20{ }^{\circ} \mathrm{C}$, $\mathrm{C}_{3} \mathrm{H}_{8} \mathrm{~N}_{2} \mathrm{O}_{3}$, rhombic, space group $F d d 2, a=24.358(9), b=18.941(6)$ and $c=5.199(2) \AA, V=2399(1) \AA^{3}, F(000)=1024, d_{\text {calc }}=1.330 \mathrm{~g} \mathrm{~cm}^{-3}$, $Z=16, \mu=0.118 \mathrm{~mm}^{-1}$.

Crystal data for 9:6(b) crystals were grown from $\mathrm{CH}_{2} \mathrm{Cl}_{2}$-hexane at $-20{ }^{\circ} \mathrm{C}, \mathrm{C}_{12} \mathrm{H}_{15} \mathrm{~N}_{2} \mathrm{O}_{4} \mathrm{Cl}$, monoclinic, space group $C 2 / c, a=17.362(2)$, $b=20.000(2)$ and $c=9.7443(8) \AA, \beta=121.10(1)^{\circ}, V=2897.1(4) \AA^{3}$, $F(000)=1200, d_{\text {calc }}=1.315 \mathrm{~g} \mathrm{~cm}^{-3}, Z=8, \mu=0.275 \mathrm{~mm}^{-1}$.

Data were measured using an Xcalibur 3 diffractometer $[T=298(\mathbf{3 b})$, $100 \mathrm{~K}(\mathbf{8}$ and 9), graphite-monochromated MoK $\alpha$ radiation, $2 \theta / \theta$ scan, $\left.2 \theta_{\max }=70^{\circ}(\mathbf{3 b}), 55^{\circ}(\mathbf{8}), 60^{\circ}(\mathbf{9})\right]$. The structures were solved by a direct method using the SHELXTL PLUS program package. ${ }^{12}$ Refinement against $F^{2}$ in an anisotropic approximation (the hydrogen atoms isotropic in the riding model, except for $\mathrm{H}$ atoms of amino groups, those were free refined) by a full matrix least-squares method for 5054 reflections was carried out to $w R_{2}=0.252$ [163 parameters, $R_{1}=0.076$ for 3368 reflections with $F>4 \sigma(F), S=1.01]$ for $\mathbf{3 b}$, for 1065 reflections were carried out to $w R_{2}=0.067$ [82 parameters, $R_{1}=0.029$ for 675 reflections with $F>4 \sigma(F), S=1.00]$ for 8 and 4090 reflections out to $w R_{2}=0.159$ [181 parameters, $R_{1}=0.058$ for 3430 reflections with $F>4 \sigma(F), S=1.08$ ] for 9 .

Atomic coordinates, bond lengths, bond angles and thermal parameters have been deposited at the Cambridge Crystallographic Data Centre (CCDC). These data can be obtained free of charge via www.ccdc.cam.uk/ conts/retrieving.html (or from the CCDC, 12 Union Road, Cambridge CB2 1EZ, UK; fax: +44 1223336 033; or deposit@ccdc.cam.ac.uk). Any request to the $\mathrm{CCDC}$ for data should quote the full literature citation and CCDC reference numbers 624636, 624635 and 632716 for $\mathbf{3 b}, \mathbf{8}$ and $\mathbf{9}$, respectively. For details, see 'Notice to Authors', Mendeleev Commun., Issue 1, 2007. 


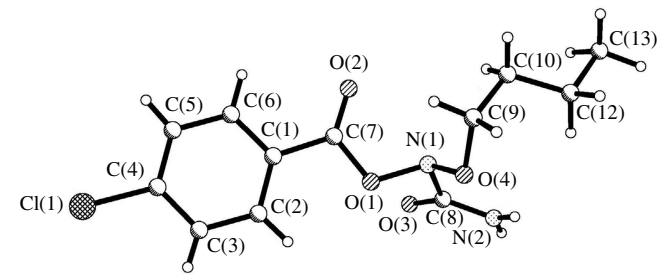

Figure 3 Molecular structure of 9 . Selected bond lengths $(\AA)$ and bond angles $\left({ }^{\circ}\right)$ : $\mathrm{N}(1)-\mathrm{O}(1) 1.447(2), \mathrm{N}(1)-\mathrm{O}(4) 1.397(2), \mathrm{N}(1)-\mathrm{C}(8) 1.441(2)$, $\mathrm{N}(2)-\mathrm{C}(8)$ 1.321(2); O(4)-N(1)-O(1) 106.4(1), O(4)-N(1)-C(8) 111.5(1), $\mathrm{O}(1)-\mathrm{N}(1)-\mathrm{C}(8) 105.9(1)$.

hybridized $\mathrm{N}(1)$ nitrogen atoms. In urea $\mathbf{3 b}$, the $\mathrm{N}(1)-\mathrm{N}(2)$ bond is shorter $[1.4254(18) \AA]$ than the corresponding bond in $N$-alkoxy- $N$-(1-pyridinium)- $N$-tert-alkylamine salts $^{8}$ [1.466(2) $\left.\AA\right]$. It may cause a lower mobility of the pyridine group in reactions of ureas 3, 4, 6 with nucleophiles.

However, the $\mathrm{N}(1)-\mathrm{N}(2)$ bond is much longer than the $\mathrm{N}-\mathrm{N}$ bonds of carboxylic acid hydrazides $(1.400 \AA) .{ }^{10}$ As it follows from quantum-chemical calculations, ${ }^{11}$ the $\mathrm{N}-\mathrm{N}$ bond in anomeric $N$-dimethylamino- $N$-methoxyformamide should be $1.385 \AA$, whereas the $\mathrm{N}-\mathrm{OMe}$ bond is longer (1.426 $\AA$ ). It is a sequence of an $n_{\mathrm{NMe}_{2}}-\sigma_{\mathrm{N}-\mathrm{OMe}}^{*}$ anomeric effect. In the cases of $N$-alkoxy$N$-(1-pyridinium)- $N$-tert-alkylamines and $N$-alkoxy- $N$-(1-pyridinium)urea salts, the opposite $n_{\mathrm{O}}-\sigma_{\mathrm{N}-\mathrm{N}^{+}}^{*}$ anomeric effect takes place, and the $\mathrm{N}(1)-\mathrm{N}(2)$ bond is destabilised. Probably, this is the reason why at boiling in methanol $N$ - $n$-propyloxy$N$-(1-pyridinium)urea chloride $\mathbf{6}$ is converted (with a moderate yield) into $N, N$-dimethoxyurea $\mathbf{1 1}$ via intermediate urea $\mathbf{1 0}$ (Scheme 3).

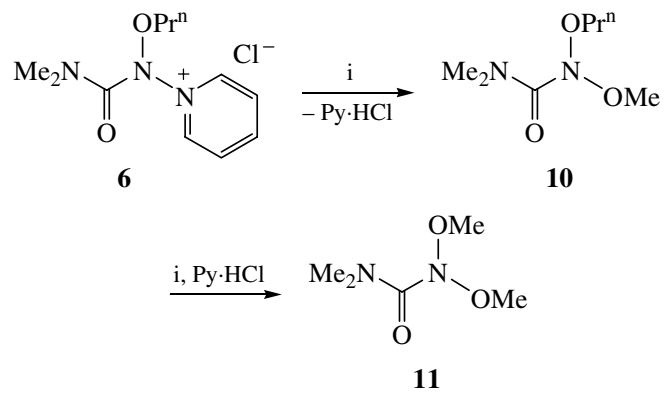

Scheme 3 Reagents and conditions: $\mathrm{i}, \mathrm{MeOH}$, reflux, $3 \mathrm{~h}$.

XRD studies of $N, N$-dimethoxyurea 8 have revealed that amide $\mathrm{O}-\mathrm{N}-\mathrm{O}$ nitrogen $\mathrm{N}(1)$ had a pyramidal configuration (Figure 2, Tables 1, 2). The pyramidality parameters $h_{\mathrm{N}}$ and $\Sigma \beta$ are close to those of $N$-acetoxy- $N$-ethoxyurea ${ }^{6(a)}$ (see Table 1 ). The carbamoyl nitrogen $\mathrm{N}(2)$ has a planar trigonal configuration; the sum of bond angles is $358.2^{\circ}$. Similarly to urea $\mathbf{3 b}$, big differences in the amide $\mathrm{N}-\mathrm{C}$ bond are observed for urea 8 . The $\mathrm{N}(1)-\mathrm{C}(1)$ bond is much longer than the $\mathrm{N}(2)-\mathrm{C}(1)$ bond (see Table 2). It is also a sequence of a bigger conjugation degree of carbonyl $\mathrm{C}(1)=\mathrm{O}(1)$ with the $s p^{2}$-hybridized $\mathrm{N}(2)$ nitrogen atom comparing with $s p^{3}$-hybridized $\mathrm{N}(1)$. The total picture of $\mathrm{N}-\mathrm{C}$ and $\mathrm{N}-\mathrm{O}$ bond deformation in anomeric ureas is given in Table 2. The carbonyl stretch frequencies of ureas $\mathbf{3 b}$ $\left(1745 \mathrm{~cm}^{-1}\right)$ and $8\left(1720 \mathrm{~cm}^{-1}\right)^{1}$ are appreciably higher than those of $N$-methoxyurea $\left(1685 \mathrm{~cm}^{-1}\right)$. The same fact was predicted and found by Glover and Rauk ${ }^{2}$ for different kinds of anomeric benzamides.

In $N, N$-dimethoxyurea 8 , the methoxy groups $\mathrm{C}(2)-\mathrm{O}(2)$ and $\mathrm{C}(3)-\mathrm{O}(3)$ have $a p$ - and $s p$-orientations, respectively, in reference to $\mathrm{Lp}(\mathrm{N} 1)$ [the torsion angle $\mathrm{Lp}(\mathrm{N} 1)-\mathrm{N}(1)-\mathrm{C}(2)-\mathrm{O}(2)$ is $174^{\circ}$, and $\mathrm{Lp}(\mathrm{N} 1)-\mathrm{N}(1)-\mathrm{C}(3)-\mathrm{O}(3)$ is $-29^{\circ}$. However, the $\mathrm{N}-\mathrm{O}$ bond lengths are close (see Table 2). The lengths of $\mathrm{C}-\mathrm{O}$ bonds are
Table 2 The lengths of $\mathrm{N}-\mathrm{O}$ bonds and amide $\mathrm{N}-\mathrm{C}$ bonds in anomeric ureas $\mathrm{H}_{2} \mathrm{~N}^{(2)} \mathrm{C}^{(1)}(\mathrm{O}) \mathrm{N}^{(1)}(\mathrm{X}) \mathrm{O}^{(1)} \mathrm{R}(\AA)$.

\begin{tabular}{lllll}
\hline $\mathrm{X}$ & $\mathrm{R}$ & $\mathrm{N}(1)-\mathrm{C}(1)$ & $\mathrm{N}(2)-\mathrm{C}(1)$ & $\mathrm{N}(1)-\mathrm{O}(1) \mathrm{R}$ \\
\hline $\mathrm{OAc}^{6(a)}$ & $\mathrm{Et}$ & 1.426 & 1.330 & 1.398 \\
$\mathrm{O}_{2} \mathrm{CC}_{6} \mathrm{H}_{4} \mathrm{Cl}-p(\mathbf{9})$ & $\mathrm{Bu}$ & 1.441 & 1.321 & 1.397 \\
$\mathrm{Cl}^{1}$ & $\mathrm{Me}$ & 1.446 & 1.319 & 1.397 \\
$\mathrm{OMe}^{(8)}$ & $\mathrm{Me}$ & 1.438 & 1.320 & $1.397,1.401$ \\
$\mathrm{~N}^{+} \mathrm{C}_{5} \mathrm{H}_{5}(\mathbf{3 b})$ & $\mathrm{Me}$ & 1.452 & 1.323 & 1.3999 \\
\hline
\end{tabular}

almost similar [O(2)-C(2), 1.431(3) ̊; O(3)-C(3), 1.429(2) ̊]]. A carbamoyl substitutent is perpendicular to the direction of $\mathrm{Lp}(\mathrm{N} 1)$ [the torsion angle $\mathrm{Lp}(\mathrm{N} 1)-\mathrm{N}(1)-\mathrm{C}(1)-\mathrm{O}(1)$ is $88^{\circ}$ ].

Thus, by means of XRD data, the nitrogen pyramidality in the $\mathrm{O}-\mathrm{N}-\mathrm{O}$ geminal systems of $N, N$-dialkoxyureas and in the $\mathrm{O}-\mathrm{N}-\mathrm{N}^{+}$geminal systems of $\mathrm{N}$-alkoxy- $\mathrm{N}$-(1-pyridinium)urea salts has been proved. It is caused by the presence of two electronegative substituents at the nitrogen atom and by the $n_{\mathrm{O}}-\sigma_{\mathrm{N}-\mathrm{X}}^{*}$ anomeric effects $\left(\mathrm{X}=\mathrm{OAlk}, \mathrm{N}^{+} \mathrm{C}_{5} \mathrm{H}_{5}\right)$. In $\mathrm{N}$-acyloxy$\mathrm{N}$-alkoxyureas, the nitrogen pyramidality degree depends on the nature of $O$-alkyl substituents.

This work was supported by the Russian Academy of Sciences and the Russian Foundation for Basic Research (grant no. 06-03-32840).

\section{References}

1 V. G. Shtamburg, O. V. Shishkin, R. I. Zubatyuk, S. V. Kravchenko, A. V. Tsygankov, A. V. Mazepa, E. A. Klots and R. G. Kostyanovsky, Mendeleev Commun., 2006, 323.

2 (a) S. A. Glover and A. Rauk, J. Org. Chem., 1996, 61, 2337; (b) S. A. Glover, Tetrahedron, 1998, 54, 7229; (c) S. A. Glover and A. Rauk, J. Org. Chem., 1999, 64, 2340.

3 I. I. Chervin, V. S. Nosova, V. F. Rudchenko, V. I. Shevchenko and R. G. Kostyanovsky, Izv. Akad. Nauk SSSR, Ser. Khim., 1986, 1148 (in Russian) (Chem. Abstr., 1986, 105, 2082129q).

4 A.-M. E. Gillson, S. A. Glover, D. J. Tucker and P. Turner, Org. Biomol. Chem., 2003, 1, 3430 .

5 S. A. Glover, G. Mo, A. Rauk, D. J. Tucker and P. Turner, J. Chem. Soc., Perkin Trans. 2, 1999, 2053.

6 (a) O. V. Shishkin, R. I. Zubatyuk, V. G. Shtamburg, A. V. Tsygankov, E. A. Klots, A. V. Mazepa and R. G. Kostyanovsky, Mendeleev Commun., 2006, 222; (b) V. G. Shtamburg, A. V. Tsygankov, E. A. Klots and R. G. Kostyanovsky, Mendeleev Commun., 2004, 208.

7 V. G. Shtamburg, E. A. Klots, A. P. Pleshkova, V. I. Avramenko, S. P. Ivonin, A. V. Tsygankov and R. G. Kostyanovsky, Izv. Akad. Nauk, Ser. Khim., 2003, 2132 (Russ. Chem. Bull., Int. Ed., 2003, 52, 2251).

8 V. G. Shtamburg, A. V. Tsygankov, E. A. Klots, I. I. Fedyanin, K. A. Lyssenko and R. G. Kostyanovsky, Mendeleev Commun., 2006, 85.

9 (a) A. J. Kirby, I. V. Komarov, P. D. Wothers and N. Feeder, Angew. Chem., Int. Ed., 1998, 37, 785; (b) A. J. Kirby, I. V. Komarov, K. Kowski and P. Rademacher, J. Chem. Soc., Perkin Trans. 2, 1999, 1313; (c) A. J. Kirby, I. V. Komarov and N. Feeder, J. Chem. Soc., Perkin Trans. 2, 2001, 522.

10 L. H. Jensen, J. Am. Chem. Soc., 1956, 78, 3993.

11 S. A. Glover, G. Mo and A. Rauk, Tetrahedron, 1999, 55, 3413.

12 G. M. Sheldrick, SHELXTL PLUS. PC Version. A System Computer Programs for the Determination of Crystal Structure from X-ray Diffraction Data. Rev. 5.1.

Received: 19th October 2006; Com. 06/2798 